ISSN : 2087-2461

PENANGGUNG JAWAB Dekan FIKOM

Evie Sofiati MI, M.I.Kom

Sekretaris Dekan

Dian Marhaeni K, M.Si

Ketua Penyunting

Made Dwi Adnjani, M.Si

Sekretaris

Mubarok, M.Si

Bendahara

Parwati, SH

Dewan Penyunting

Trimanah, M.Si

Edi Ismoyo, M.Si

Suharyoso, S.Sos

Seksi Usaha

Endang Winarsih, S.Sos

Sirkulasi dan Distribusi

Aldino Leoniv, ST

Alamat Redaksi

Fakultas Ilmu Komunikasi

Universitas Islam

Sultan Agung Semarang

J1. Raya Kaligawe Km. 4

Po. Box 1054/SM

Semarang 50112

Telp. (024) 6583584

ext. $448 / 449$

Fax. (024) 6582455

email : jurnalfikom@yahoo.com
Pengaruh Perubahan Nama Terhadap Citra Pada Telkom

University

Felesia Ekafaya Kirianawati, Roro Retno Wulan,

Kharisma Nasionalita

felesiaekafay@gmail.com

Komunikasi Lintas Budaya Etnis India, Etnis China serta

Pribumi di kampung Lubuk Pakam

Meilani Dhamayanti

mdhamayanti73@gmail.com

Analisis Komunikasi Pemasaran Melalui Strategi Brand Activation Pond's Untuk Meraih Top Brand Award 2013 Rustono Farady Marta ${ }^{1}$, Pricillia ${ }^{2}$, Maria Fransisca Kosasih ${ }^{3}$, Maria Christina Evelyn Iskandar ${ }^{4}$

rustonofarady@gmail.com ${ }^{1}$, icil_22@hotmail.com ${ }^{2}$, s43_s43@yahoo.com ${ }^{3}$,

mariachristinaevelyne@gmail.com ${ }^{4}$

Analisis Isi Visual Iklan Dan Strategi Kreatif Kategori Print Ad Pemenang Gold, Silver, dan Bronze Citra Pariwara 2015

Dina Nur Handayani ${ }^{1}$ (dinurhdyn@gmail.com)

Ratih Hasanah Sudrajat ${ }^{2}$ (kumaharatih@gmail.com ${ }^{2)}$

Ayub Ilfandy Imran ${ }^{3}$ (a_ilfandy@yahoo.com ${ }^{3}$ )

Refleksi Citra Indonesia Sebagai Dampak Politik Migrasi TKI

ke Malaysia

Mutia Rahmi Pratiwi (mutiarahmipratiwi@gmail.com)

Amida Yusriana (amidayusriana88@gmail.com)

$46-59$

Karakteristik Press Release Praktisi Public Relations Hotel di Yogyakarta

Margaretha Sonya, Meylani Yo, Nobertus Ribut Santoso

margaretha_sonyalee@yahoo.com

$60-70$

Isu LGBT dalam Bingkai Media Online

Muhammad Ghifari Putra ${ }^{1}{ }^{1}$ ghifarigp@gmail.com)

Kharisma Nasionalita ${ }^{2}$

${ }^{2}$ nasionalita.kharisma@gmail.com

$71-87$

Telepon Selular dan Ruang Publik : Representasi Identitas Siswantini

yjuliman@gmail.com

$88-94$

Kepemilikan dan Bingkai Media (Analisis Framing Pemberitaan Joko Widodo Sebagai Kandidat Calon Presiden pada Koran SINDO)

Nani Kurniasaril (nani.kurniasari@kalbis.ac.id ${ }^{1}$ )

Gilang GustiAji² (gilangaji@unesa.ac.id²)

$96-116$ 


\title{
KEPEMILIKAN DAN BINGKAI MEDIA (ANALISIS FRAMING PEMBERITAAN JOKO WIDODO SEBAGAI KANDIDAT CALON PRESIDEN PADA KORAN SINDO)
}

\author{
Oleh : \\ Nani Kurniasari, Gilang Gusti Aji \\ Institut Teknologi dan Bisnis Kalbis, Universitas Negeri Surabaya \\ nani.kurniasari@kalbis.ac.id gilangaji@unesa.ac.id
}

\begin{abstract}
The activities of several media in the presidential election in 2014 reflect the increasing role of the media in the succession election process. The problem is, there is the issue of independence that surfaced because of the news that is not balanced when the election period. Several previous studies linking patterns of news like that with the issue of media ownership. Media owner is considered to have a vested interest in the content that is raised. Reese and Shoemaker (1996) believes the media content is influenced by many factors, media ownership is one of them. This study approached by the qualitative way using Gamson-Mondigliani framing analysis. Taking Koran Sindo in the MNC group by Hari Tanoesoedibjo as research object, this research shows that there is an attempt framing the news of Joko Widodo in a negative tone. Framing by Koran Sindo hinted at a hidden agenda behind the text message of the media. Like support previous research, this study proves that media content is not a reflection of actual reality, but shaped by various factors that produce different versions of reality. There is factor of ownership that influence agenda of media text.
\end{abstract}

Keywords: framing, media ownership, mass media, reporting, presidential election.

\begin{abstract}
Abstrak
Aktivitas beberapa media dalam pemilihan presiden tahun 2014 menjadi cermin meningkatnya peran media dalam proses suksesi pemilihan. Masalahnya, ada isu independensi yang mengemuka karena pemberitaan yang tidak berimbang saat masa pemilihan. Beberapa penelitian terdahulu menghubungkan pola pemberitaan seperti itu dengan isu kepemilikan media. Pemilik media dianggap memiliki kepentingan pribadi atas konten yang dimunculkan. Reese dan Shoemaker (1996) meyakini konten media dipengaruhi berbagai faktor, salah satunya kepemilikan media. Penelitian ini didekati secara kualitatif menggunakan analisis framing dari Gamson-Mondigliani. Mengambil objek penelitian Koran Sindo yang berada dalam grup MNC milik Hari Tanoesoedibjo, penelitian ini menunjukkan bahwa ada upaya pembingkaian berita tentang sosok Joko Widodo secara negatif. Pembingkaian yang dilakukan Koran Sindo mengisyaratkan agenda tersembunyi di balik teks berita yang disampaikan media. Seakan mendukung riset terdahulu, penelitian ini membuktikan bahwa isi media bukanlah sebuah cermin dari realitas yang sebenarnya, tetapi dibentuk oleh berbagai faktor yang menghasilkan berbagai versi yang berbeda dari realitas. Ada faktor kepemilikan yang memberikan pengaruh pada agenda penyusunan teks media.
\end{abstract}

Kata kunci: framing, kepemilikan media, media massa, pemberitaan, pemilihan presiden. 


\section{Pendahuluan}

Menguatnya peran media massa dalam proses komunikasi politik semakin terasa menjelang pemilihan umum. Media merupakan salah satu aktor penting dalam menggiring opini audiens. Selain menjadi wadah informasi, mediajugamempunyai peran menjadikan proses demokrasi di Indonesia akan semakin baik dan bermutu. Secara ideal, dalam setiap pemberitaannya, media harus selalu berusaha netral dan mengutamakan kepentingan bangsa.

Persoalannya, dalam memberitakan kandidat calon presiden, mengemuka isu independensi media. Sejumlah elit politik yang juga berstatus sebagai taipan media massa menggunakan dan memanfaatkan media massa dalam memuluskan kepentingan politik mereka. Isi media yang ditampilkan sarat akan kepentingan politik pemilik media tersebut. Padahal, esensi media semestinya menjaga fungsi idealnya. Seperti yang diungkapkan Denis McQuail (2002), juga Undang-Undang Pers, idealisme jurnalisme dan media harus menyajikan informasi yang mencerdaskan dan memberdayakan publik agar mereka bisa mengatur diri sendiri. Kepentingan publik adalah alasan utama eksistensi jurnalisme. Maka, independensi dan netralitas menjadi elemen penting dalam menjalankan profesi ini.

Bahasan tentang independensi dan netralitas media bermula dari isu kepemilikan media di Indonesia. Beberapa tahun terakhir terjadiperkembangan signifikan dalamkonteks kepemilikan media ini. Penelitian Nugroho dkk (1991) tentang lanskap sektor media di Indonesia menunjukkan bahwa era reformasi merupakan titik melesatnya perkembangan bisnis media. Dalam lima belas tahun terakhir, pertumbuhan industri media di Indonesia telah didorong oleh kepentingan modal yang mengarah pada oligopoli dan pemusatan kepemilikan. Ia juga menghasilkan pemetaan terhadap para pelaku di mana terdapat 12 grup media besar di Indonesia. Hasil pemetaan tersebut menunjukkan bahwa ada tiga grup media yang sangat besar di antara kedua belas kelompok. Grup MNC sebagai salah satu yang terbesar memiliki 20 stasiun televisi (termasuk stasiun lokal dan stasiun televisi berlangganan), lebih dari 20 stasiun radio, serta 7 media cetak.

Ade Armando (2014) melihat media massa mengalami proses komersialisasi yang menyebabkannya menjelma menjadi bisnis yang memiliki nilai ekonomi tinggi. Perkembangan ini mengubah karakter mereka yang terlibat dalam dunia media. Bahkan ruang redaksi pun harus tunduk pada logika rating sebagai prasyarat memperoleh iklan. Dalam konteks ini, jurnalis bukan lagi aktivis demokrasi,melainkanprofesionaldalamentitas bisnis. Di abad 21 ini, media massa didirikan untuk tujuan komersial oleh para pengusaha yang melihat keuntungan ekonomi yang bisa diperoleh dari bisnis media. Pendiri media adalah pengusaha yang menguasai bisnis yang terdiversifikasi secara luas. Lebih jauh lagi, pengusaha media ini memiliki kepentingan politik dan sebagian lagi menjadi kandidat yang memperebutkan posisi pejabat publik. Lebih lanjut, Ade Armando mengidentifikasi salah satu dampak utama dari perkembangan terakhir ini adalah keterlibatan pemilik dalam proses produksi media. Pemilik menuntut para profesional yang bekerja di perusahaan media yang dimilikinya untuk melahirkan produk yang membawa keuntungan. Di sisi lain, pemilik mengarahkan media untuk mempromosikan dan melindungi kepentingan politik dan ekonomi mereka. Ancaman terbesarnya terletak pada independensi dan objektivitas media.

Dalam konteks komunikasi massa, khususnya komunikasi pemasaran politik, media massa bukan hanya menjadi bagian integral dari politik tetapi juga memiliki posisi yang sentral. Media massa merupakan saluran komunikasi politik yang banyak digunakan untuk menyebarluaskan informasi, terkait berbagai hal mengenai citra secara masif dan menjangkau khalayak yang begitu jauh, beragam, dan luas terpencar. Demikian juga halnya peran media massa yang dapat menjadi sumber primer masyarakat dalam 
mendapatkan informasi mengenai pilpres Indonesia 2014.

Melalui kapasitas dan kompetensinya untuk membuat, menggerakkan, atau bahkan membalikkan opini publik, media massa bisa menjadi penentu. Dalam memberitakan sebuah peristiwa, media massa tidak berdiri bebas dari kepentingan. Media massa melakukan seleksi atas isu apa yang akan ditampilkan dan dihilangkan. Dengan demikian bingkai (frame) menjadi bagian terpenting yang dilakukan oleh media massa karena akan memengaruhi khalayak untuk melakukan pemaknaan atas permasalahan yang diungkap oleh media massa. Atas dasar asumsi tersebut, sebuah media massa mempunyai peran yang sangat penting dalam menyatukan isu di masyarakat dengan cara memberikan arah dan prioritas pemberitaan. Sehingga media berhasil mengumpulkan semangat masyarakat, menggerakkan wacana perubahan, dan memobilisasi masyarakat dalam rangka mewujudkan suatu tujuan. Ia menjadi kekuatan yang dominan untuk menentukan tindak lanjut apa yang seharusnya ataupun tidak dilakukan. Framing media massa berlaku pada saat penentuan judul berita, ukuran huruf untuk judul, penempatannya di halaman berapa, dan julukan apa yang dipilih untuk membela atau menyudutkan kelompok tertentu. Dengan demikian, teks media bukanlah peristiwa sebenarnya. Keterlibatan wartawan dan editor berperan dalam mem-frame sebuah berita (Wicks, 2005: 340).

Melalui kapasitas dan kompetensinya untuk membuat, menggerakkan, atau bahkan membalikkan opini publik, media massa bisa menjadi penentu. Di satu sisi, media berdiri di atas prinsip pelayanan terhadap khalayak dengan menyediakan informasi dan pandangan berdasarkan nilai kepentingan dan kebutuhan dari khalayak itu sendiri. Dalam posisi seperti ini, media harus menjadi mandiri dari negara maupun kepentingan dari penguasa ataupun pemilik modal. Namun di sisi lain, media juga menyediakan informasi dengan konten yang ditentukan oleh negara maupun penguasa yang berkepentingan.
Secara normatif, dalam membingkai berbagai realitas yang begitu luas, media massa diharapkan dapat berlaku independen dan proporsional. Secara umum, etika profesional di seluruh media adalah-seperti diungkap oleh Roger (dalam Norris, 1999: 1) media massa seharusnya dapat melaporkan secara objektif dan harus merepresentasikan fakta secara adil tanpa bias, dalam bahasa yang didesain tidak ambigu dan tidak terdistorsi. Termasuk dalam memberitakan rentetan fakta yang terjadi selama berlangsungnya masa kampanye. Media diharapkan dapat menjaga netralitas dan tidak memihak. Di sini, media massa dituntut menjaga kejujuran (honesty), akurasi (accuracy), dan keseimbangan (fairness).

Dari sisi moralitas, Kode Etik Jurnalistik (KEJ) dari berbagai organisasi wartawan Indonesia pun secara tegas telah menggariskan bahwa wartawan dalam menyajikan sebuah fakta harus dapat bersikap adil, berimbang, mengutamakan prinsip "cover both sides" dan tidak berupaya mencampuradukkan antara fakta dan opini. Berita harus disajikan secara lengkap, akurat, dan tidak mengandung unsur perbedaan Suku, Agama, Ras, dan Antargolongan (SARA). Namun demikian, problematika dalam media massa adalah seberapapun besarnya media massa menyediakan ruang khusus, tetap saja ruang itu memiliki keterbatasan. Menjadi hal yang tidak mungkin jika semua fakta yang begitu banyak dapat diberitakan secara keseluruhan. Dengan demikian, berita yang tampil di media massa sebenarnya berupa penggalan-penggalan fakta atau realitas sosial yang ada di ruang publik dan telah dipilih oleh redaksi media massa untuk diproses secara jurnalistik dan disajikan menjadi sebuah berita. Media harus memilih, memilah, menonjolkan, menyembunyikan, dan memberikan frame (bingkai) pemberitaan dari rangkaian peristiwa yang ada di ruang publik.

Hal-hal yang telah disebutkan sebelumnya, menjadikan adanya kemungkinan bias dan kecenderungan pemberitaan pada kepentingan-kepentingan tertentu. Dalam 
situasi demikian, media massa tidak dapat lagi berperan sebagai saluran yang pasif, netral, dan sekadar menjadi kumpulan medium yang melaporkan informasi. Akan tetapi, media massa telah menjadi arena sosial atau panggung publik, yaitu sebuah arena di mana berbagai kelompok kepentingan saling berusaha menampilkan definisi situasi, serta definisi realitas sosial menurut versi mereka sendiri (Nugroho, 1991: viii).

Dengan besarnya tuntutan publik atas media dan keterbatasan sumber daya membuat posisi media massa di dalam upayanya memuaskan semua pihak menjadi hal yang bisa disebut hampir mustahil. Di tengah-tengah keterbatasan ruang di satu sisi dan banyaknya aktivitas politik selama masa kampanye yang berlangsung dalam waktu relatif bersamaan di sisi yang lain, menjadikan media massa harus mengambil sikap. Keterbatasan-keterbatasan ini, ditambah dengan latar belakang, sejarah pendirian media, ideologi, dan orientasi keberpihakan menjadikan media massa harus melakukan pembingkaian terhadap fakta-fakta sosial-politik yang terjadi.

Secara lebih lanjut, individu-individu atau awak media massa juga memiliki perspektif dan pandangan tersendiri dalam menyikapi sebuah realitas. Masing-masing individu yang terlibat di dalam pekerjaan media massa, membangun realitas subyektif terhadap sebuah fakta. Hal ini menyebabkan terjadinya dinamika internal dalam sebuah mekanisme kerja redaksi. Satu di antara yang lain saling mewarnai. Sintesis dari proses dialektika itulah yang menjadi realitas simbolik media.

Media massa berperan sebagai salah satu tumpuan utama dalam menyebarluaskan informasi, media massa justru seringkali menjadi arena perang antarkelompok kepentingan. Di sini, media massa sering disalahgunakan menjadi ajang penyebaran dan penguatan pengaruh tertentu. Kegiatan-kegiatan seperti konferensi pers, jumpa pers, pemberian fasilitas selama liputan, dan pengiriman press release adalah kegiatan yang sering dilakukan dalam rangka menjalin hubungan yang baik dengan media.
Pada akhir abad ke-19, Amerika menemukan 'korporasi' sebagai bentuk organisasi yang mampu melakukan produksi dan distribusi atas budaya (teks dan komunikasi) yang kemudian disebarluaskan kepada komunikator. Menjadi bagian yang penting adalah bahwa bentuk industrialisasi dari komunikasi akan membuat intelektual menjadi terlembagakan yang bekerja dalam organisasi serta harus mengikuti aturan yang belaku (hierarki dan mekanistik). Sehingga komunikator dan medium (koran/TV/radio dan saluran budaya lainnya) menjadi terlembagakan. Dengan demikian produk budaya (teks) memiliki perbedaan apabila dibandingkan pada saat komunikator dan medium tidak terlembagakan. Hingga lahirlah era industrialisasi media massa, yang artinya, mau tidak mau agar bisa bertahan hidup, media massa harus dikelola dengan asas profit oriented. Walaupun tidak sepenuhnya, arus kepentingan ekonomi dan ideologi pasar membuat pilihan dan ruang manuver para awak media massa menjadi sangat terbatas. Dalam kondisi ini media hanya sebatas meliput konflik dan cenderung tidak memerhatikan konteks karena acuan utamanya adalah oplah penjualan.

Pengusaha media sudah tidak bisa lagi mengandalkan idealisme dalam mengelola perusahaan, tetapi harus meningkatkannya menjadi industri (McQuail, 2002: 260). Media massa berperan menyebarkan berita-berita kepada khalayak luas dalam waktu singkat. Selanjutnya, khalayak seringkali terpengaruh oleh sisi-sisi yang ditonjolkan atau ditekankan oleh media dan mungkin sedikit mengabaikan atau mengesampingkan beberapa fakta sosial politik. Kondisi ini dapat memengaruhi proses kognisi dan persepsi individu terhadap gagasan, komunikasi, dan kesimpulan yang diambil oleh individu. Sebaliknya, beberapa khalayak menghendaki adanya proses seleksi atas kesesuaian opini dengan fakta. Persepsi tersebut akan menimbulkan rentang yang cukup lebar bagi posisi khalayak dalam mengambil sikap terhadap gagasan, konflik, dan komunikasi yang dibangun. Hal ini juga diungkapkan dalam teori konsistensi kognitif (cognitive dissonance) yaitu teori 
yang memprediksi bahwa khalayak akan cenderung mencari informasi atau gagasan yang memelihara konsistensi dan menghindari opini yang tidak seusai atau bias (Festinger, 1957).

Terdapat dua isu penting yang hendak dikaji dalam penelitian ini. Pertama, soal bagaimana kepentingan pemilik tercermin dalam pemberitaan suatu media. Media massa bukan hanya sekadar sarana yang menampilkan sebuah peristiwa secara apa adanya, tetapi juga tergantung kepada kelompok atau siapa pemilik yang mendominasinya, dengan kata lain adanya unsur kepemilikan yang memengaruhi peristiwa tersebut. Curran \& Gurevitch (2005), mengatakan bahwa kepentingan pemilik media dikhawatirkan akan memengaruhi pesan yang disampaikan media dan hegemoni ideologi media yang akhirnya berpengaruh kepada khalayak (Subiakto \& Ida, 2012: 140). Bahkan pengaruh pemilik media juga berdampak pada pemberitaan konten media. Dengan adanya intervensi dari kepemilikan media, maka secara tidak langsung masyarakat telah "dipilihkan"e dalam membaca sebuah beia Apalagi jika berita tersebut berkaitan dengan kegiatan pemilik media.

Kedua, peranan media massa cukup signifikan dalam mengedukasi masyarakat dalam pemilu. Seharusnya media massa dapat menjadi referensi bagi pemilih untuk memberikan pencerahan kepada masyarakat agar warga sebagai pemilih mengetahui rekam jejak calon. Sejumlah studi menunjukkan bahwa media memiliki kekuatan yang besar dalam memengaruhi agenda publik. Sehingga media massa perlu membuat agenda-setting yang jelas dan mengambil angle yang sesuai dengan medianya masing-masing, tentu berpihak pada rakyat, namun harus tetap dalam koridor menjalankan fungsi pers, mengedukasi masyarakat dengan tetap melakukan fungsi pengawasan (watch dog).

Pendekatan framing analysis di level teks pada media discourse analysis menjadi grounded theory dari penelitian ini, karena peneliti menilai berita mengenai kegiatan/komunikasi politik pada masa kampanye menim- bulkan wacana-wacana yang menarik apabila dikaji dari sudut pandang komunikasi massa.

Peneliti melihat analisis framing menjadi alat yang tepat untuk melihat bagaimana cara wartawan menyusun fakta-fakta dan peristiwa-peristiwa sosial-politik yang terjadi (melalui struktur berita, latar informasi, kutipan sumber), kemudian bagaimana awak media menuangkan fakta-fakta tersebut menjadi sebuah karya jurnalistik (melalui kelengkapan berita $5 \mathrm{~W}+1 \mathrm{H}$ ), baik itu dari gaya awak media menulis fakta (melalui detail koherensi, bentuk kalimat, kata ganti), maupun dari cara awak media memberikan penekanan-penekanan pada beberapa fakta tertentu. Kecenderungan wartawan dalam memahami suatu peristiwa, termasuk dalam pemberitaan seorang kandidat calon presiden dapat diamati dengan analisis framing tersebut.

Wicks (2005: 345) menyarankan dalam melakukan penelitian framing para peneliti harus melakukan penelitian dari empat perspektif, pertama pembentukan frame merupakan pendekatan yang berbasis dengan jurnalis dan melibatkan konstruksi dan penyusunan frame untuk membuat informasi dapat diterima. Sehingga ideologi, sikap jurnalis dan termasuk rutinitas media akan terlibat. Kedua, setting frame hampir sama dengan asumsi agenda-setting. Bila agenda-setting lebih banyak berpusat pada penonjolan isu, framing banyak berbicara mengenai penonjolan atribut isu. Ketiga, efek pada level individu dari framing berasumsi adanya hubungan antara frame media dengan outcome pada level individu. Keempat, jurnalis sebagai khalayak berasumsi mengenai sebuah posisi yang konsisten dengan teori skema di mana jurnalis adalah $\operatorname{cog}$ nitive misers, sama seperti khalayak, jurnalis dapat memilih dan menonjolkan frame yang digunakan media.

Sementara, beberapa faktor berpengaruh dalam pembentukan framing sebuah teks berita (Wicks, 2005: 342-343), yakni orientasi politik atau ekonomi, praktik dan keterbatasan organisatoris, sistem kepercayaan jurnalistik dan upaya untuk menarik khalayak. Semua pertimbangan tersebut tidak hanya 
terbatas pada pertimbangan ekonomi semata, akan tetapi juga memperhatian belief systems yang dimiliki oleh media tersebut. Meskipun demikian, tiga dari faktor yang ada tersebut memang mengedepankan orientasi pendapatan keuntungan (ekonomi) semata.

Penelitian ini hendak melihat bagaimana media massa memberitakan seorang kandidat calon presiden. Untuk mendapatkan gambaran tersebut, peneliti mengambil objek penelitian pemberitaan Koran Sindo yang dimiliki oleh Hari Tanoesudibjo. Penelitian ini menggunakan perangkat-perangkat framing analysis oleh Gamson-Modigliani. Akan dilihat apakah media massa membentuk struktur tertentu dalam berbagai isu yang berkembang selama masa kampanye. Karena penulis meyakini apa yang disebutkan Rogers (dalam Norris, 1999: 10) bahwa institusi media massa dalam menyajikan berita selalu mengambil angle-angle tertentu, baik secara sosial, ekonomi, maupun politis. Apa yang diberitakan oleh media massa atau jurnalis adalah artikulasi dari sebuah posisi ideologi khusus yang dianut oleh media massa atau jurnalis tersebut.

Berdasarkan latar belakang tersebut maka pertanyaan penelitian ini adalah bagaimana Koran Sindo memberitakan Jokowi pada masa kampanye pemilihan presiden (pilpres) 2014? Dengan demikian, tujuan penelitian ini adalah untuk memahami secara mendalam mengenai framing yang dilakukan oleh Koran Sindo dalam memberitakan Jokowi pada masa kampanye pilpres 2014.

Penelitian ini secara praktis diharapkan dapat bermanfaat bagi para pakar dan pemerhati politik, peneliti dan analis media, serta masyarakat akademis secara luas sehingga dapat mengetahui lebih mendalam bahwa media massa dalam membingkai sebuah kejadian didasarkan kecenderungan tertentu yang dapat memengaruhi persepsi dan opini publik.

Penelitian ini secara teoritis-akademis hendak mengkaji dan meneliti secara mendalam bagaimana media ternyata memiliki sikap dan kebijakan khusus dalam peristiwa pilpres 2014. Selain itu, penelitian ini diharap- kan dapat memberikan kontribusi berarti bagi pengembangan dan perluasan teori-teori yang sudah ada terutama teori dan model framing.

Wicks (2005: 349-350) dalam Communication Yearbook 29 mengemukakan bahwa penelitian framing banyak berfokus mengenai pembentukan makna dalam konteks pengemasan pesan, pengaruh praktisi hubungan masyarakat, praktik, dan norma dari organisasi media. Framing biasanya mengandalkan tampilan visual daripada isu yang diusung. Berbagai kritik yang sering dilayangkan mengenai pemberitaan selama masa kampanye pilpres 2014 adalah media tidak fokus pada isu. Berbagai informasi yang diberikan selama masa kampanye sering mencerminkan usaha media untuk menarik perhatian khalayak dengan cara menyajikan tampilan yang menarik dengan memberikan sedikit informasi yang baru.

\section{Metodologi}

Penelitian ini menggunakan analisis framing, yaitu analisis yang melihat wacana sebagai hasil dari konstruksi realitas sosial, maka penelitian ini termasuk ke dalam paradigma konstruktivis. Paradigma konstruktivis mempunyai posisi dan pandangan tersendiri terhadap media dan teks berita yang dihasilkannya. Konstruktivis memandang realitas kehidupan sosial bukanlah realitas yang natural, tetapi hasil konstruksi. Karenanya konsentrasi analisis pada paradigma konstruktivis adalah menemukan bagaimana peristiwa atau realitas tersebut dikonstruksi dan dengan cara apa konstruksi itu dibentuk. Konstruktivis melihat bahwa realitas yang diciptakan oleh media menjadi realitas yang dimiliki masyarakat. Melalui media, pemilik media berusaha menanamkan ideologi dan pemahamannya terhadap sebuah permasalahan, sehingga realitas yang diciptakan oleh media bukanlah realitas yang sebenarnya.

Penelitian ini didekati secara kualitatif melalui telaah teks dalam Koran Sindo dengan analisis framing dari Gamson-Mondigliani. Gamson-Mondigliani (dalam Nugroho, Eri- 
yanto, Surdiasis, 1999: 21-22) menyebut cara pandang sebagai kemasan (package) yang mengandung konstruksi makna atas peristiwa yang akan diberitakan. Menurut GamsonModigliani, frame adalah cara bercerita atau gugusan ide-ide yang terorganisasi sedemikian rupa dan menghadirkan konstruksi makna peristiwa yang berkaitan dengan objek suatu wacana.

Berdasarkan konsepnya, Gamson mendefinisikan framing dalam dua pendekatan, yaitu pendekatan kultural yang menghasilkan framing dalam level kultural dan pendekatan psikologis yang menghasilkan framing dalam level individual. Dalam level kultural, frame dapat dimaknai sebagai batasan-batasan wacana serta elemen-elemen konstitutif yang tersebar dalam konstruksi wacana. Sedangkan asumsi dasar dari framing level individu adalah bahwa individu selalu bertindak atau mengambil keputusan secara sadar, rasional, dan intensional. Individu selalu menyertakan pengalaman hidup, wawasan sosial, dan kecenderungan psikologisnya dalam menginterpretasi pesan yang diterima.

Teknik pengolahan data yang akan dilakukan pada penelitian ini berdasarkan pada formula atau analisis framing dari GamsonModigliani (dalam Eriyanto, 2005: 225) karena dianggap sesuai dengan penelitian yang akan dilakukan. Perangkat framing yang mereka sajikan yaitu meneliti media melalui gagasan sentral yang kemudian didukung oleh perangkat-perangkat wacana dalam konstruksi berita. Pengolahan data pada penelitian ini dilakukan dengan langkah-langkah: (1) menganalisis frame, yaitu ide suatu peristiwa yang berkaitan dengan objek suatu wacana, (2) menganalisis perangkat framing, yakni berupa metaphors (perumpamaan atau pengandaian), catchphrases (frase menarik, kontras ataupun menonjol), exemplaar (kaitan dengan contoh), depiction (kosakata, leksikon), dan visual image (gambar), (3) menganalisis perangkat penalaran, yakni berupa roots (analisis sebab akibat), appeals to principles (klaim moral), consequences (konsekuensi yang didapat dari frame), (4) mengolah hasil penelitian.

\section{Gambar 1 Skema Framing Analysis Model} Gamson dan Modigliani

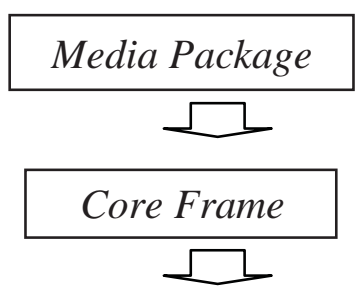

\begin{tabular}{|c|c|}
\hline \multicolumn{2}{|c|}{ Condensing Symbols } \\
\hline Framing Devices & Reasoning Devices \\
\hline $\begin{array}{ll}\text { 1. } & \text { Metaphors } \\
\text { 2. } & \text { Exemplaar } \\
\text { 3. } & \text { Catchphrases } \\
\text { 4. } & \text { Depictions } \\
\text { 5. } & \text { Visual Images }\end{array}$ & $\begin{array}{l}\text { 1. Roots } \\
\text { 2. Appeal to } \\
\text { Principle }\end{array}$ \\
\hline
\end{tabular}

Sumber: Alex Sobur, "Analisis Teks Media: Suatu Pengantar untuk Analisis Wacana, Analisis Semiotik, dan Analisis Framing". Bandung: PT. Remaja Rosdakarya, 2002, hlm. 177.

Model Gamson-Modigliani didasarkan pada pendekatan konstruktivis yang melihat representasi media berupa berita dan artikel, terdiri atas package interpretatif yang mengandung konstruksi makna tertentu. Dalam package ini terdapat dua struktur, yaitu core frame dan condensing symbols. Struktur pertama merupakan pusat organisasi elemenelemen ide yang membantu komunikator untuk menunjukkan substansi isu yang tengah dibicarakan. Sedangkan struktur yang kedua mengandung dua substruktur, yaitu framing devices dan reasoning devices.

Core frame (gagasan sentral) pada dasarnya berisi elemen-elemen inti untuk memberikan pengertian yang relevan terhadap peristiwa dan mengarahkan makna isu yang dibangun condensing symbol (simbol yang "dimantapkan"). Condensing symbol adalah hasil pencermatan terhadap interaksi perangkat simbolik (framing devices dan reasoning devices) sebagai dasar digunakannya perspektif. Simbol dalam wacana terlihat transparan bila dalam dirinya menyusup perangkat bermakna yang mampu berperan sebagai pan- 
duan menggantikan sesuatu yang lain.

Nimmo (1993: 80-82) membedakan referential symbol dan condensing symbol. Referential symbol menunjuk pada kategorikategori khusus atau umum dari objekobjek baik fisik, sosial, maupun abstrak dan memiliki makna denotatif. Makna yang dihubungkan dengan simbol ini terdiri dari orientasi-orientasi terhadap simbol itu sendiri dan bukan terhadap apapun yang khusus, yang ditunjukkannya.

Struktur framing devices yang mencakup metaphors, exemplaar, catchphrases, depictions, dan visual images menekankan aspek bagaimana "melihat" suatu isu. Struktur reasoning devices menekankan aspek pembenaran terhadap cara "melihat" isu, yakni roots (analisis kausal) dan appeals to principle (klaim moral).

Secara literal methapors dipahami sebagai cara memindah makna dengan merelasikan dua fakta melalui analogi atau memakai kiasan dengan menggunakan katakata seperti, ibarat, bak, sebagai, umpama, laksana. John Fiske (dalam Imawan, 2000:

66) menilai metafora sebagai common sense, pengalaman hidup keseharian yang di-taken for granted masyarakat. Common sense terlihat alamiah (kenyataannya diproduksi secara arbitrer) dan perlahan-lahan menjadi kekuatan ideologis kelas dominan dalam memperluas dan mempertahankan ide untuk seluruh kelas. Metafora berperan ganda, pertama sebagai perangkat diskursif dan ekspresi piranti mental. Kedua, berasosiasi dengan asumsi atau penilaian, serta memaksa teks membuat sense tertentu.

Exemplaar mengemas fakta tertentu secara mendalam agar satu sisi memiliki bobot makna lebih untuk dijadikan rujukan atau pelajaran. Posisinya menjadi pelengkap bingkai inti dalam kesatuan berita untuk membenarkan perspektif. Catchphrases, istilah, bentukan kata, atau frase khas cerminan fakta yang merujuk pemikiran atau semangat tertentu. Dalam teks berita catchphrases mewujud dalam bentuk jargon, slogan, atau semboyan.
Depictions, penggambaran fakta dengan memakai kata, istilah, kalimat konotatif agar khalayak terarah ke citra tertentu. Dengan asumsi pemakaian kata khusus diniatkan untuk membangkitkan prasangka, menyesatkan pikiran dan tindakan, serta efektif sebagai bentuk aksi politik. Depictions dapat berbentuk stigmatisasi, eufemisme, serta akronimisasi.

Visual images, pemakaian foto, diagram, infografis, tabel, kartun, dan sejenisnya untuk mengekspresikan kesan, misalnya perhatian atau penolakan, dibesarkan, dikecilkan, ditebalkan atau dimiringkan, serta pemakaian warna. Visual image bersifat sangat natural, mewakili realitas yang membuat erat muatan ideologi pesan dengan khalayak. Roots (analisis kausal), pembenaran isu dengan menghubungkan satu objek atau lebih yang dianggap menjadi sebab timbulnya atau terjadinya hal yang lain. Tujuannya membenarkan penyimpulan fakta berdasar hubungan sebab-akibat yang digambarkan atau dibeberkan.

Gunther Kress dan Theo Van Leeuwen menyatakan penataan visual images halaman surat kabar bukan sekadar alasan estetika perwajahan tetapi lebih merupakan proses memengaruhi lewat efek dan fungsi pesan agar menancap di benak khalayak, termasuk aspek ideologi, pengaruh, dan subjektivitas yang bersatu padu. Secara ideologis Van Dijk menandaskan fungsi visual images adalah untuk memanipulasi fakta agar bermakna legitimate. Sebab menurut Stuart Allan, visual lebih berdaya memindah realitas dalam wacana dibanding teks/polysemy (dalam Siahaan, 2001: 86).

Appeal to principle, pemikiran, prinsip, klaim moral sebagai argumentasi pembenar membangun berita, berupa pepatah, cerita rakyat, mitos, doktrin, ajaran, dan sejenisnya. Appeal to principle yang apriori, dogmatis, simplistik, dan monokausal (nonlogis) bertujuan membuat khalayak tak berdaya menyanggah argumentasi. Fokusnya memanipulasi emosi agar mengarah ke sifat, waktu, tempat, cara tertentu, serta membuatnya tertutup atau keras dari bentuk penalaran lain. 
Dedi N. Hidayat membuat model atau kerangka analisis framing lain yang diadopsi dari kerangka analisis yang digunakan Gamson-Modigliani. Frame pembangunan yang dijadikan model tersebut merupakan perspektif atau sudut pandang yang digunakan oleh media untuk mengemas berbagai isu serta peristiwa. Frame "pembangunan" tersebut terbentuk oleh seperangkat instrumen pembingkai (framing devies) serta instrumen penalar (reasoning devices).

Frames terdiri atas framing devices yang berfungsi mengarahkan individu guna mendefinisikan apa yang "sebenarnya" menjadi isu di balik rangkaian fakta, serta reasoning devices yang berperan memandu penentuan sikap dan tindakan (Gamson dan Lasch, 1983 dalam Hidayat, 2001).

Kita bisa mengetahui framing devices (yang mengarahkan bagaimana cara melihat isu) suatu media lewat keajegan penggunaan berbagai metafor, visualisasi, dan exemplaar. Sementara reasoning devices (yang memberikan alasan pembenar apa yang seharusnya dilakukan terhadap isu tersebut) suatu media dapat dideteksi melalui roots (analisis kausal), serta appeal to principle (imbauan atau klaim moral) yang diketengahkan media.

Ini sejalan dengan empat fungsi frames sebagaimana dikatakan Entman (dalam Siahaan, 2001: 81). Keempat fungsi frames itu adalah pertama, mendefinisikan masalah dengan menetapkan apa yang dilakukan agen kausal, dengan biaya dan keuntungan apa, biasanya diukur dengan nilai-nilai budaya bersama. Kedua, mendiagnosis penyebab dengan mengidentifikasi kekuatan yang menciptakan masalah. Ketiga, melalukan penilaian moral dengan mengevaluasi agen-agen kausal dan dampak-dampaknya. Keempat, menyarankan perbaikannya dengan menawarkan dan memberikan pembenaran terhadap penanganan masalah, serta memprediksi kemungkinan akibatnya. Pada dasarnya sebuah kalimat bisa menampilkan lebih dari satu fungsi framing tersebut meski kalimat yang banyak dalam suatu teks dapat pula tidak menampilkan satu pun dari keempat fungsi tersebut. Begitu pula sebuah frame dalam beberapa teks khusus tak selalu harus memasukkan seluruh fungsi itu.

\section{Hasil dan Pembahasan}

Koran Sindo (Seputar Indonesia) merupakan bagian dari MNC Group yang berada di bawah naungan Global Media Com (MNC). Terbit pertama kali pada 2005. Selain nasional, harian ini tersebar di seluruh wilayah Indonesia dengan nama Koran Sindo Jabar, Koran Sindo Jateng, Koran Sindo Yogya, Koran Sindo Jatim, Koran Sindo Medan, Koran Sindo Makassar, Koran Sindo Palembang. Koran Sindo dibagi menjadi tiga bagian yaitu: news, sport \& lifestyle. Oplah Koran Sindo berkisar sekitar 330.000 eksemplar. Selain beredar secara reguler melalui jalur distribusi konvesional (agen), Koran Sindo juga didistribusikan melalui jalur distribusi mandiri berdasarkan database pelanggan Indovision di Jabodetabek, database para CEO di Jakarta, dan database area publik di Jakarta seperti hotel, rumah sakit, penerbangan, galeri, cafe, dan mal. MNC Group dimiliki oleh Hary Tanoesoedibjo yang mengawali karir politiknya dengan bergabung pada partai Nasdem, tetapi setelah Surya Paloh terpilih menjadi Ketua Umum, dia mengundurkan diri dan memutuskan bergabung dengan partai Hati Nurani Rakyat (Hanura) pimpinan Wiranto. Pada pemilu 2014, Hary Tanoesoedibjo maju sebagai calon wakil presiden dari partai Hanura.

\section{Pemberitaan Calon Presiden} Indonesia pada Pemilu 2014. Kandidat yang bersaing ketat pada pemilihan presiden Indonesia 2014 tentu tidak luput dari pemberitaan media massa nasional. Namun, apakah media massa dalam hal ini surat kabar di Indonesia sudah berimbang dalam melakukan pemberitaan. Data yang digunakan dalam penelitian ini adalah pemberitaan mengenai Jokowi di Koran Sindo dalam kurun waktu terhitung sejak 5 Juni 2014 sampai dengan 5 Juli 2014 dengan pertimbangan bahwa dalam rentang waktu tersebut ditetapkan sebagai masa kampanye terbuka pemilihan presiden 2014, dengan asumsi bahwa pada masa tersebut tim pemenangan bersaing memanfaatkan media 
untuk menyampaikan pesan politik calon presidennya kepada masyarakat. Demikian juga media massa secara aktif menggulirkan isu-isu terkait untuk memberikan informasi kepada masyarakat sehingga masyarakat akan mudah dalam menentukan pilihannya. Total pemberitaan Jokowi di Koran Sindo selama masa kampanye terbuka adalah sejumlah 9 berita dengan rincian terlihat pada tabel 1 di bawah ini:

Tabel 1 Pemberitaan Jokowi di Koran Sindo

\begin{tabular}{|l|l|l|}
\hline \multicolumn{1}{|c|}{ Edisi } & Halaman & \multicolumn{1}{c|}{ Judul } \\
\hline Kamis, 5 Juni 2014 & 1 & Jokowi Kehilangan Pamor di Jakarta \\
\hline Sabtu, 21 Juni 2014 & 1 dan 15 & Pengelolaan APBD DKI Memburuk \\
\hline Sabtu, 24 Juni 2014 & 3 & Jokowi Dinilai Tak Kuasai Persoalan Internasional \\
\hline Selasa, 25 Juni 2014 & 3 & Soal Indosat, Jokowi Menuai Kritik \\
\hline Jumat, 27 Juni 2014 & 1 dan 15 & Anggaran DKI Memburuk, DPRD Panggil Jokowi \\
\hline Sabtu, 28 Juni 2014 & 2 & Revolusi Mental Jokowi Jadi Polemik \\
\hline Senin, 30 Juni 2014 & 2 & Jokowi Dinilai Salah Kaprah \\
\hline Sabtu, 5 Juli 2014 & 2 & Ribuan Warga Doakan Jokowi-JK \\
\hline Sabtu, 5 Juli 2014 & 2 & Jokowi-JK Siap Buktikan Visi Misi \\
\hline
\end{tabular}

Hasil Analisis Framing Pemberitaan Jokowi di Koran Sindo. Koran Sindo menyorot sosok Jokowi dengan tone yang negatif. Salah satunya ialah membandingkan tingkat elektabilitas dalam sebuah hasil survei. Terdapat beberapa berita yang menggunakan pola tersebut. Misalnya pada headline berita tanggal 5 Juni 2014 yang dengan judulnya lantang menyebutkan Jokowi kehilangan pamor di Jakarta. Dalam berita tersebut, Koran Sindo mengutip hasil penelitian Lingkaran Survei Indonesia (LSI) yang menyatakan keunggulan Prabowo di wilayah yang langsung dipimpin sendiri oleh Jokowi sebagai Gubernur. Koran Sindo mengutip hasil survei seperti di bawah ini:

Posisi DKI Jakarta dalam peta pertarungan pilpres cukup penting. Menurut catatan lembaga riset itu, Jakarta memiliki basis populasi $4 \%$ dari total jumlah pemilih nasional. Dari proporsi tersebut, PrabowoHatta mendapatkan dukungan 35\%, sementara Jokowi-JK menghimpun $30,66 \%$. Responden yang memutuskan untuk merahasiakan pilihan, belum memutuskan, tidak tahu, dan tidak jelas mencapai $34,34 \%$.

Sumber: Koran Sindo, 5 Juni 2014.
Pola serupa terjadi di tanggal 27 Juni 2014 pada berita yang berjudul Prabowo Lampaui Jokowi di headline halaman satu. Dalam berita tersebut Koran Sindo memanfaatkan ulasan media internasional untuk melakukan pembingkaian yaitu Sidney Morning Herald (SMH). Peneliti menduga penggunaan media Internasional tersebut sebagai langkah mengukuhkan kredibilitas hasil survei. Ulasan yang dikutip misalnya:

SMH juga mengulas beberapa hasil survei. Pada awal Juni, Lembaga Survei Indonesia (LSI) menyebutkan keunggulan Jokowi telah menyempit menjadi $6,3 \%$ atau turun dari sebelumnya sebesar 20\% pada awal 2014 dibandingkan Prabowo. Dan, pada Senin (23/6) lalu, sebuah lembaga survei yang lain menunjukkan Prabowo memiliki elektabilitas 51,2\% dibandingkan Jokowi 48,8\%.

Sumber: Koran Sindo, 27 Juni 2014.

Pemberitaan hasil survei masih dilakukan oleh Koran Sindo. Dalam berita yang berjudul Prabowo-Hatta diprediksi menang 53\% tanggal 30 Juni 2014, Koran Sindo mengutip hasil survei Indo Barometer. 
Menariknya hasil survei sebenarnya masih menunjukkan keunggulan pasangan JokowiJK. Tetapi dengan salah satu aspek tentang hasil survei tersebut dalam berita ini yang ingin dibangun sejak awal, yaitu:

Lembaga survei Indo Barometer bahkan memerkirakan Prabowo-Hatta akan mengalahkan Joko Widodo-Jusuf Kalla (Jokowi-JK) dengan perolehan suara $53 \%$ berbanding $47 \%$. Angka kemenangan untuk Prabowo-Hatta tersebut akan terwujud jika pasangan yang diusung koalisi Merah Putih itu mampu mempertahankan tren elektabilitas yang terus menanjak selama masa kampanye pilpres berlangsung.

Sumber: Koran Sindo, 30 Juni 2014.

Untuk mengukuhkan keunggulan Prabowo-Hatta atas Jokowi-JK, dikutip pula sebuah hasil riset Lembaga Survei Nasional (LSN) sebagai berikut:

Survei LSN yang melibatkan 1.070 responden di 34 provinsi ini menunjukkan pasangan PrabowoHatta meraih suara $46,6 \%$, sementara Jokowi-JK memperoleh 39,9\%.

Sumber: Koran Sindo, 30 Juni 2014.

Publikasi hasil survei jamak dilakukan dalam berita politik untuk memberikan gambaran posisi elektabilitas kandidat. Namun peneliti meyakini bahwa publikasi hasil survei ini tidaklah bebas nilai. Dalam proses menuju pemilihan umum, dalam hal ini pemilihan presiden, hal itu bisa saja dilakukan untuk membangun sebuah pemahaman pemilih. Pernah dikenal yang disebut efek bandwagon atau efek yang membuat orang mengikuti apa yang dipercaya sebagai "yang menang".

Sosok Jokowi pun dimunculkan sebagai seorang Gubernur Jakarta. Pada saat itu memang Jokowi masih menjalankan amanatnya pada tahun kedua. Tercatat satu kali Koran Sindo menampilkannya sebagai seorang Ke- pala Daerah yaitu pada tanggal 21 Juni 2014. Berita yang berjudul "Pengelolaan APBD DKI Memburuk" berupaya menunjukkan kualitas kepemimpinan Jokowi sebagai Gubernur. Dalam berita tersebut, Koran Sindo pun sudah mengawali dengan fakta temuan Badan Pemeriksa Keuangan (BPK) sebagai berikut:

Benarkah DKI Jakarta di bawah kepemimpinan Gubernur Joko Widodo (Jokowi) sudah melaksanakan tata kelola keuangan dengan baik? Badan Pemeriksa Keuangan (BPK) justru mendapatkan 86 temuan dengan nilai kerugian mencapai Rp1,54 triliun dalam laporan pengelolaan Anggaran Pendapatan Belanja Daerah (APBD) DKI 2013.

Sumber: Koran Sindo, 21 Juni 2014.

Selanjutnya Koran Sindo memberikan konteks historis pada hasil temuan tersebut dengan memunculkan fakta tahun-tahun sebelumnya:

Atas temuan tersebut, BPK memberikan penilaian Wajar dengan Pengecualian (WDP) terhadap Laporan Keuangan Pemerintah Provinsi DKI Jakarta Tahun Anggaran 2013. Penilaian tersebut lebih buruk dibandingkan dengan perolehan tahun 2011 dan 2012, yakni Wajar Tanpa Pengecualian (WTP).

Sumber: Koran Sindo, 21 Juni 2014.

Pemunculan fakta negatif tentang kapasitas kepemimpinan Jokowi sebagai Gubernur DKI ini dinilai oleh peneliti sebagai sebuah upaya perlawanan isu. Selama ini, publik relatif mengenal sosok nomor satu di Jakarta itu sebagai seorang yang peduli dan bekerja untuk rakyat. Pemunculan fakta seperti ini diduga mampu membalik anggapan tersebut.

Analisis tersebut mesti ditarik ke konteks yang lebih tinggi yaitu dalam perhelatan pemilihan presiden 2014. Dalam proses menuju pemilihan, pemilih diharapkan secara rasional melakukan pertimbangan 
terhadap kualitas kepemimpinan kandidat. Media punya peran untuk menampilkan hasil kinerja kepemimpinan seorang kandidat. Dugaan inilah yang diyakini peneliti mendorong Koran Sindo mengupayakan pemunculan fakta-fakta lain tentang Jokowi demi mencapai tujuan yang diinginkan.

Tipe pembingkaian lain pada sosok Jokowi yang dilakukan Koran Sindo ialah pemberitaan pascadebat capres. Debat capres memang beberapa kali dilakukan dalam proses menuju pemilihan presiden. Dalam salah satu beritanya pada Selasa 24 Juni 2014 Koran Sindo memberikan penilaian terhadap Joko Widodo. Berita yang berjudul "Jokowi Dinilai Tak Kuasai Persoalan Internasional” berupaya menunjukkan kurangnya kapasitas kandidat tersebut dengan memanfaatkan pendapat ahli, seperti:

Direktur Institut Madani Nusantara Prof. Nanat Fatah Natsir menilai Jokowi terkesan tidak menguasai isu Laut China Selatan sebagaimana pertanyaan Prabowo Subianto. "Pertanyaan yang dilontarkan Prabowo tentang konflik Laut China Selatan sangat bagus dan aktual. Sayang jawaban Jokowi terkesan tidak menguasai masalah," kata Nanat di Jakarta kemarin.

Sumber: Koran Sindo, 24 Juni 2014.

Pembahasan pemikiran Jokowi dalam debat ditunjukkan pula pada berita lainnya. Esoknya, Rabu 25 Juni 2014, Koran Sindo membahas isu penjualan Indosat yang dilakukan pada era kepemimpinan Megawati. Terhadap jawaban Jokowi yang menyatakan bahwa penjualan tersebut dilakukan karena krisis moneter, Koran Sindo menggunakan kutipan Marwan Batubara, Direktur Eksekutif Indonesian Resources Studies (IRESS). Marwan menilai, keputusan menjual PT Indosat di era kepemimpinan Presiden Megawati Soekarnoputri adalah kesalahan fatal.

Menurut Marwan, jawaban Jokowi atas pertanyaan yang dilontarkan Prabowo

\begin{abstract}
Subianto dalam debat bertema "Politik Internasional dan Ketahanan Nasional" itu harus diluruskan. "Jadi Jokowi harus belajar sejarah. Kita waktu itu sebetulnya sudah recover dari krisis," tandasnya.
\end{abstract}

Sumber: Koran Sindo, 25 Juni 2014.

Masih tentang pemikiran Jokowi, Koran Sindo kembali melakukan analisis. Kali ini soal revolusi mental, jargon yang kerap didengungkan oleh calon presiden nomor urut dua itu. Dalam berita tanggal 28 Juni 2014, Koran Sindo menayangkan berita berjudul "Revolusi Mental Jokowi Jadi Polemik". Dalam berita tersebut istilah revolusi mental dianggap berakar dari ajaran sosialis komunis yang di kawasan Eropa dipahami untuk mendobrak kungkungan ajaran agama. Koran Sindo mengutip pendapat Habib Alatas, peneliti Pusat Kajian Politik Islam dan Pancasila sebagai berikut:

Menurut dia, istilah revolusi mental ini tidak hanya pernah dipakai di Eropa, tapi juga digunakan oleh pendiri Partai Komunis China yang bernama Chen Duxiu bersama rekannya, Li Dazhao. Istilah itu untuk mencuci otak kaum buruh dan petani dalam rangka menentang kekaisaran China waktu itu. "Di Indonesia istilah ini mulai dipakai Ahmad Aidit, anak dari Abdullah Aidit, yang mengganti namanya menjadi Dipa Nusantara Aidit (DN Aidit)," ungkapnya.

Sumber: Koran Sindo, 28 Juni 2014.

Pada dua perhelatan pemilu terakhir, tradisi debat menjadi perkembangan penting dalam demokrasi. Pada Pilpres 2014 ini, debat memegang peranan penting sebagai ajang masyarakat menilai kualitas pemikiran dan penampilan calon pemimpinnya. Ajang tersebut biasanya disusul oleh assessment yang dilakukan media tentang hasil debat, pemikiran, visi-misi, dan lainnya. 
Terhadap pemikiran yang disampaikan oleh Jokowi, Koran Sindo beberapa kali memunculkan hasil analisisnya dengan meminjam pendapat para ahli. Dalam berbagai pemberitaan tersebut jelas sekali tone yang muncul bersifat negatif. Pemikiran Jokowi dijelaskan sebagai yang tidak feasible dan sosoknya ditampilkan sebagai sosok yang kurang kompeten pada permasalahan bangsa.

Frame Koran Sindo untuk menampilkan Jokowi sebagai calon presiden yang tidak kompeten dan tak layak dipilih dalam pemilihan presiden 2014 diperkuat dengan simbol-simbol tertentu untuk memberi penekanan atau penonjolan pada apa yang ingin disampaikan melalui perangkat pembingkai (framing devices). Simbol-simbol tertentu digunakan sebagai pembenar untuk menonjolkan sebuah isu. Sehingga, khalayak pembaca dapat lebih mudah dan menerima frame yang telah dibentuk oleh redaksi.

Dalam pemberitaan hasil riset, Koran Sindo secara intens menggambarkan pola perubahan tingkat keterpilihan yang dinamis dalam proses menuju pilpres 2014. Perangkat pembingkaian Koran Sindo menekankan adanya penurunan popularitas elektabilitas yang dialami oleh Jokowi. Hal tersebut dilakukan misalnya dengan memunculkan metafora "kehilangan pamor" dalam berita tanggal 5 Juni 2014.

Metafora tersebut digunakan untuk menyatakan bahwa semakin berjalannya waktu, popularitas Jokowi yang dulu sempat melambung makin menunjukkan tren yang kurang menggembirakan. Seperti yang kita tahu, Jokowi ialah sosok yang popularitasnya sangat tinggi. Koran Sindo dengan memanfaatkan hasil survei ingin memberikan penekanan popularitas Jokowi yang menurun di wilayah kepemimpinannya sendiri.

Dalam melakukan pembingkaian, Koran Sindo pun menggunakan label (depiction). Misalnya label Jokowi yang "meninggalkan Jakarta", untuk menonjolkan langkah kurang bertanggung jawab dengan meninggalkan pekerjaan yang belum diselesaikannya. Jokowi masih memiliki tiga tahun masa kepemimpi- nan di propinsi DKI Jakarta. Penggunaan label tersebut oleh Koran Sindo menunjukkan bahwa surat kabar ini berusaha melakukan manipulasi simbolis untuk menekankan bahwa calon presiden haruslah bertanggung jawab.

Temuan peneliti menunjukkan dominannya berita publikasi hasil survei. Semua berita tersebut memberikan klaim bahwa popularitas Prabowo meningkat dan sebaliknya, Jokowi menurun. Untuk mendukung klaim tersebut diperlukan sebuah ilustrasi (exemplaar) pada fakta. Misalnya seperti pada kutipan di bawah ini tentang penjelasan bagaimana elektabilitas Jokowi yang menurun:

Menurut dia, pemilih rasional banyak yang beralih ke Prabowo setelah melihat penampilannya pada debat kandidat yang menawarkan konsep makro tentang kepemimpinan nasional. Pemilih rasional ini, kata dia, sangat paham tentang konsep makro yang ditawarkan Prabowo tersebut. Pada saat yang sama Jokowi lebih banyak bicara pada tataran mikro dengan gaya bahasa yang cenderung diarahkan pada kalangan menengah ke bawah. "Padahal, selama ini pemilih Jokowi memang adalah kalangan menengah ke bawah ini. Akibatnya, dia gagal meraih dukungan pemilih rasional," ujar dia.

Sumber: Koran Sindo, 30 Juni 2014.

Pola yang sama dilakukan pula pada berita tanggal 30 Juni 2014. Berita berjudul "Prabowo Diprediksi Menang 53\%" melakukan klaim tentang prediksi kemenangan Prabowo jika tren yang terjadi konsisten. Tren yang dimaksud ialah kenaikan elektabilitas Prabowo yang tentu diikuti penurunan keterpilihan Jokowi. Menariknya, hasil penelitian yang dirilis Indo Barometer kemudian masih menunjukkan keunggulan pasangan Jokowi-JK. Maka, peneliti melihat bahwa Koran Sindo menyusun sebuah ilustrasi untuk menunjukkan tren penurunan tersebut. Mengutip pendapat Heri Budianto, Pakar Komunikasi Politik Universitas Mercubuana, 
Sindo memberikan konteks penurunan Jokowi tersebut sebagai berikut:

Pakar komunikasi politik dari Universitas Mercu Buana, Jakarta, Heri Budianto mengatakan, salah satu penyebab elektabilitas Jokowi-JK terus anjlok adalah kegagalan capres nomor urut

2 tersebut dalam menciptakan diferensiasi pemilih. Jokowi yang selama ini kuat di pemilih kalangan menengah bawah tidak cukup mampu merebut simpati pemilih rasional. Pemilih rasional adalah kelas menengah atas yang aktif mengakses informasi, termasuk mengamati proses jalannya debat kandidat.

Sumber: Koran Sindo, 30 Juni 2014.

Sama seperti langkah sebelumnya, ilustrasi (exemplaar) ini disusun untuk memberikan konteks pada isu yang ditekankan. Dalam berita ini, Koran Sindo berupaya keras untuk mendukung klaim yang dilakukannya di judul tentang prediksi kemenangan PrabowoHatta meski riset menunjukkan hal itu masih harus melalui berbagai syarat. Ilustrasi dalam konteks ini digunakan untuk melakukan pembenaran pada bingkai yang hendak disusun.

Pembingkaian berita memerlukan istilah-istilah untuk mendukungnya. Ini kerap disebut catchphrases. Dalam berita tanggal 25 Juni 2014 berjudul "Soal Indosat, Jokowi Menuai Kritik" Koran Sindo hendak memberikan ulasan tentang jawaban-jawaban Jokowi ketika debat tentang penjualan Indosat beberapa tahun silam. Isu tersebut diangkat kembali dan menjadi bahan menarik untuk melakukan pembingkaian pada Jokowi dan gerbong politiknya. Penjualan Indosat sendiri dilakukan saat kepemimpinan presiden Megawati Soekarnoputri. Menariknya, di berita tersebut dimunculkan sebuah istilah unik dalam sebuah kutipan di bawah ini:

Menurut Marwan, jawaban Jokowi atas pertanyaan yang dilontarkan Prabowo Subianto dalam debat bertema"Politik
Internasional dan Ketahanan Nasional" itu harus diluruskan. "Jadi Jokowi harus belajar sejarah. Kita waktu itu sebetulnya sudah recover dari krisis," tandasnya.

Sumber: Koran Sindo, 25 Juni 2014.

Istilah harus belajar sejarah mengandung makna yang menarik. Hal tersebut berangkat dari istilah yang pernah dipopulerkan Bung Karno yaitu jangan sekali-sekali melupakan sejarah. Koran Sindo ingin mendukung bingkai yang disusun tentang "dosa masa lalu" Partai Demokrasi Indonesia Perjuangan (PDIP) dan Megawati yang mengusung Jokowi sebagai calon presiden. Mengaitkan istilah yang diciptakan Bung Karno dengan kesalahan yang dilakukan saat ini oleh penerusnya.

Pembingkaian berita tidak melulu dilakukan dengan teks saja namun seringkali melibatkan unsur pendukung seperti foto, diagram, tabel dan sejenisnya. Upaya mendukung pembingkaian dengan kekuatan visual (visual images) bisa dicontohkan pada berita tanggal 21 Juni 2014 berjudul "Pengelolaan APBD DKI Memburuk". Berita tersebut menjelaskan laporan BPK tentang kerugian yang dialami Pemerintah Provinsi DKI Jakarta dalam APBD 2013.

Untuk memvisualisasikannya, Koran Sindo memunculkan gambar kartu Jakarta pintar yang berlubang dan mengeluarkan air dalam jumlah besar. Simbol kebocoran ini berupaya menguatkan bingkai yang ingin dibangun tentang kebocoran pengelolaan APBD. Penggunaan Kartu Jakarta Pintar pun menarik mengingat program ini merupakan andalan kepemimpinan Jokowi-Ahok. 
Gambar 2 Kartu Jakarta Pintar Bocor di Koran Sindo

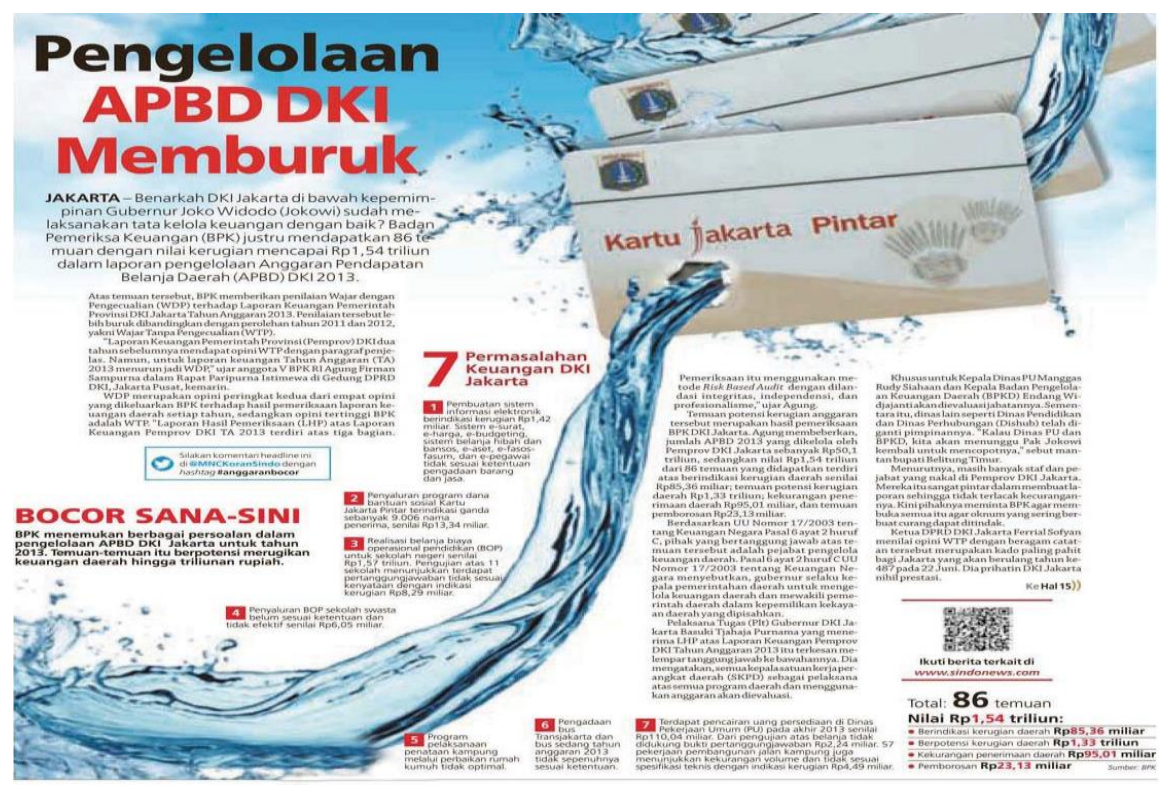

Sumber: Koran Sindo, Sabtu, 21 Juni 2014.

Perangkat kedua menurut GamsonModigliani adalah perangkat penalaran (reasoning devices) yang mengacu pada hubungan atau koherensi dari teks berita tersebut pada sebuah gagasan tertentu. Gagasan tersebut tidak hanya terdiri dari kata atau kalimat, tetapi juga memiliki dasar tertentu atau alasan tertentu. Guna perangkat penalaran yaitu untuk menekankan "berita" yang disampaikan sebuah media dalam teks adalah benar (Eriyanto, 2002, pp. 217-249). Teks berita Koran Sindo tentang sosok Jokowi sebagai calon presiden dilakukan dalam beberapa pola. Misalnya analisis kausal untuk menunjukkan hubungan sebab akibat dalam sebuah persoalan ditonjolkan melalui roots yang tampak dalam kutipan di bawah ini:

Agung Suprio menilai tren turunnya dukungan Jokowi-JK di Jakarta disebabkan oleh beberapa faktor, misalnya warga yang kecewa dengan sikap Jokowi yang memilih meninggalkan Jakarta. Di samping itu ada beberapa isu negatif seperti halnya kasus dugaan korupsi pengadaan Transjakarta yang ditangani Kejaksaan Agung (Kejagung).

Sumber: Koran Sindo, 5 Juni 2014.
Kutipan tersebut dimunculkan untuk menjelaskan fakta hasil survei yang dipublikasikan sekaligus untuk menguatkan pembingkaian tentang bagaimana Jokowi kehilangan popularitas di Jakarta. Dengan ilustrasi tersebut, data dan fakta yang muncul mampu dilengkapi sehingga terlihat rasional dan membangun pembenaran pada konstruksi bahwa Jokowi telah kehilangan pamor.

Koran Sindo memperkuat perangkat penalaran tersebut dengan klaim-klaim moral tertentu (appeals to principle), dengan mengutip pernyataan dari Fadli Zon, Wakil Ketua Umum DPR yang juga Wakil Ketua Umum Partai Gerindra, yang menyatakan:

Fadli Zon, menilai Jokowi tak paham persoalan di Laut China Selatan. Padahal, wilayah Indonesia bisa saja diklaim sebagai akibat konflik itu. "Di sini bisa terjadi suatu klaim terhadap perairan di atas wilayah utara Natuna oleh kekuatan yang besar. Kita harus terlibat secara proaktif, jangan sampai kita kaget dan tiba-tiba berhadapan dengan kekuatan besar," papar Fadli.

Sumber: Koran Sindo, 24 Juni 2014.

Kutipan tersebut ingin menyiratkan sebuah prinsip di mana seharusnya Indonesia terlibat aktif untuk mengantisipasi hal-hal 
buruk yang mungkin terjadi. Upaya proaktif tersebut pada intinya dilakukan untuk menjaga kedaulatan serta keamanan negara. Prinsip moral ini dimunculkan untuk membuat khalayak susah menyanggah isi argumentasi.

\section{Tabel 4.3 Frame Koran Sindo}

\begin{tabular}{|l|l|}
\hline \multicolumn{2}{|c|}{ Frame: Kualitas Kepemimpinan Jokowi } \\
\hline $\begin{array}{l}\text { Methapors } \\
\text { Istilah kehilangan } \\
\text { pamor di Jakarta } \\
\text { untuk menggambarkan } \\
\text { menurunnya popularitas } \\
\text { Jokowi di daerah yang } \\
\text { pernah dimenangkannya. }\end{array}$ & $\begin{array}{l}\text { Roots } \\
\text { Publik Jakarta } \\
\text { kecewa dengan } \\
\text { programinaskan brogram } \\
\text { yang dijanjikan. }\end{array}$ \\
$\begin{array}{l}\text { Catchpharases } \\
\text { Jokowi harus belajar } \\
\text { sejarah, istilah yang } \\
\text { dicetuskan Soekarno namun } \\
\text { kemudian diingkari oleh } \\
\text { penerusnya. }\end{array}$ & $\begin{array}{l}\text { Appeals to principle } \\
\text { Kewajiban terlibat } \\
\text { proaktif dalam } \\
\text { isu konflik Laut } \\
\text { Cina Selatan } \\
\text { untuk melindungi } \\
\text { kedaulatan. }\end{array}$ \\
\hline $\begin{array}{l}\text { Exemplaar } \\
\text { Gaya bahasa Jokowi yang } \\
\text { cenderung untuk kalangan } \\
\text { menengah ke bawah } \\
\text { membuatnya kehilangan } \\
\text { pemilih rasional }\end{array}$ & $\begin{array}{l}\text { Consequences } \\
\text { Popularitas dan } \\
\text { elektabilitas } \\
\text { Prabowo meningkat. }\end{array}$ \\
\hline $\begin{array}{l}\text { Depiction } \\
\text { Jabel Meninggalkantuk } \\
\text { menggambarkan Jokowi } \\
\text { yang melepaskan diri dari } \\
\text { tanggung jawab. }\end{array}$ & $\begin{array}{l}\text { Jakarta pintar yang } \\
\text { bocor dengan aliran } \\
\text { air yang kencang. }\end{array}$ \\
\hline
\end{tabular}

Analisis Kepemilikan Media. Demokrasipadahakikatnyaadalahkomunikasi. Salah satu aspek pentingnya ialah pensyaratan hak untuk berbicara (berkomunikasi) dan hak untuk menyampaikan pendapat menjadi asasi bagi setiap manusia untuk dilindungi, apakah itu dilakukan secara langsung di depan publik atau disampaikan melalui media massa. Tanpa adanya kebebasan berpikir dan kebebasan menyatakan pendapat, maka manusia tidak dapat hidup sesuai dengan fitrah kemanusiannya. Karena itu, tidak adil dan tidak benar jika ada pihak lain yang berusaha membatasi, mengurangi, menghalangi atau melarang seseorang menuangkan pikiran dan menyatakan pendapatnya.

Kebebasan berpendapat di Indonesia mendapatkan basis hukum dalam UUD 1945 pasal 28 F. Pasal tersebut dijelaskan bahwa setiap orang berhak untuk berkomunikasi dan memperoleh informasi untuk mengembangkan pribadi dan lingkungan sosialnya, serta berhak untuk mencari, memperoleh, memiliki, menyimpan, mengolah, dan menyampaikan informasi dengan menggunakan segala jenis saluran yang tersedia. Itu berarti masyarakat boleh mencari segala macam informasi yang dibutuhkan tanpa terkecuali.

Oleh sebab itu, pers sebagai media komunikasi menjadi salah satu pilar dalam penegakan demokrasi harus dibebaskan dari intervensi pemerintah dan memberi perlindungan kepada siapa saja (sumber) yang inginmengemukakanpikirandanpendapatnya. Pemberian kebebasan ini menjadi tuntutan hampir semua elemen media, karena media massa dipandang sebagai cerminan suara hati masyarakat di bawah prinsip kebebasan untuk berbicara (freedom to speech), dan kebebasan untuk menyampaikan pendapat (freedom of the press) kepada orang lain tanpa dikenakan sensor dan pembreidelan.

Iklim demokrasi media massa mengemban peranan yang sangat penting seperti dijelaskan oleh Brian McNair, Communication (1997: 21), yaitu (1) media harus memberikan informasi kepada masyarakat (citizens) tentang apa yang terjadi di sekitar mereka (surveillance function and monitoriung function of media), (2) media harus mendidik sehingga informasi mempunyai signifikansi dengan fakta, (3) media harus memiliki platform untuk wacana politik publik, memfasilitasi bentuk-bentuk opini publik, (4) media memberi publisitas beragam kegiatan pemerintah dan lembaga-lembaga politik sebagai peran watch dog journalist, (5) media dalam masyarakat demokrastis melayani sebagai channel advokasi pandangan-pandangan politik.

Untuk mengukur tingkat kebebasan dan tanggung jawab media massa, Frederick 
S. Siebert, Paterson dan Wilbur Schramm (1963) membuat formula sistem pers termasuk televisi dan radio atas empat sistem. Salah satu yang diharapkan sesuai di Indonesia ialah Sistem Pers Tanggung Jawab Sosial. Model ini diajukan oleh para teoritisi setelah melihat kemungkinan bahaya yang bisa ditimbulkan oleh sistem pers liberal. Melihat adanya ketidakstabilan masyarakat dalam bentuk kebobrokan moral, meningkatnya kriminalitas dan intervensi media yang terlalu jauh pada aspek-aspek privasi seseorang, serta kecenderungan media menjadikan masyarakat semata-mata sebagai konsumen yang bisa mendatangkan uang melalui penjualan surat kabar kuning dan iklan-iklan yang tidak beretika. Sistem ini merekomendasikan agar media memiliki tanggung jawab sosial untuk menyelamatkan dan mendidik masyarakat. Dalam sistem ini, pers diharapkan berperan sebagai:(1)pemberiinformasiyang terpercaya, akurat, objektif dan seimbang, (2) berfungsi sebagai forum untuk pertukaran komentar dan kritik, (3) memberi gambaran yang benarbenar mewakili kelompok-kelompok dalam masyarakat, (4) menyajikan tujuan dan nilainilai masyarakat, (5) menyediakan akses penuh terhadap informasi yang tersembunyi pada suatu saat.

Media massa memiliki peran yang cukup signifikan dalam berlangsungnya proses demokratisasi. Bahkan Edmund Burke menyebut, media massa merupakan pilar keempat demokrasi setelah eksekutif, legislatif dan yudikatif. Tak heran jika Burke menyematkan pers sebagai pilar keempat demokrasi. Merujuk peran ideal yang dimainkan, pers memang menjadi tulang punggung demokrasi. Setidaknya ada empat lakon yang dijalani:

(1) jurnalisme sebagai sumber informasi yang mendidik masyarakat, (2) jurnalisme menjadi pengawas penguasa (watch dog) dalam menjalankan pemerintahan, (3) jurnalisme sebagai penyambung lidah (mediator) antara publik dan pemerintah, dan (4) jurnalisme sebagai ruang advokasi publik.

Meski demikian, pers juga terkadang memainkan peran ganda. Jurnalisme di sam- ping memiliki peran ideal, ia juga merupakan sebuah industri yang tak lekang dari kungkungan kapitalisme. McNair (1997) mengatakan, "media bukanlah ranah yang netral di mana berbagai kepentingan dan pemaknaan dari berbagai kelompok akan mendapatkan perlakuan yang sama dan seimbang. Media justru bisa menjadi subjek yang mengkonstruksi realitas berdasarkan penafsiran dan definisinya sendiri untuk disebarkan pada khalayak.

Seperti yang dibayangkan oleh McNair di atas, media sedang menguat sebagai kekuatan bisnis alih-alih institusi sosial. Realitas media massa Indonesia saat ini ialah cermin watak kapitalisme yang mengunggulkan upaya menumpuk modal dan keuntungan. Hal itu tercermin baik dalam aspek struktur media maupun isi media.

Menguatnya kapitalisme pasar dalam industri media ini menjadi pintu terciptanya kecenderungan konglomerasi media, konsentrasi pasar, dan kepemilikan silang. Struktur industri media di Indonesia kini dicirikan dengan tendensi konsentrasi kepemilikan. Isu konsentrasi kepemilikan media sudah sejak lama menjadi perhatian ilmuwan-ilmuwan komunikasi. McQuail (2000: 144) menyatakan bahwa isu tentang kepemilikan (ownership) merupakan salah satu isu utama dari lima isu saat berbicara tentang media dan masyarakat.

Dalam konteks Indonesia, Yanuar Nugroho (2011) memaparkan percepatan konglomerasi industri media di Indonesia. Saat ini, ada 12 kelompok media besar yang mengendalikan sebagian besar kanal media di Indonesia. Sebagian besar dari mereka juga memiliki bisnis lain yang berkaitan dengan properti. Contohnya Grup Kompas, yang memiliki bisnis properti berupa convention centre, dan CT Group, yang selain memiliki dua stasiun televisi juga memiliki bisnis perbankan dan bisnis properti di bawah bendera Trans Property.

Terlebih lagi, dengan adanya beberapa pemilik media yang juga berprofesi sebagai politisi, mereka akan diuntungkan karena dapat menggunakan media yang mereka miliki untuk menciptakan opini publik sesuai dengan 
kehendak mereka. Contoh yang sangat jelas adalah Surya Paloh, pemilik Media Group (MetroTV dan surat kabar Media Indonesia) serta Aburizal Bakrie, yang memiliki Viva Group. Media-media ini telah membantu mereka membentuk opini publik yang tentu menguntungkan kepentingan mereka dengan cara yang dapat dengan mudah dijelaskan melalui 'Hypodermic Needle Theory'

Media massa diyakini memiliki kemampuan memengaruhi publik dalam banyak cara, salah satunya adalah apa yang disebut $a g$ enda-setting. McComb dan Reynolds (2002: 1) menjelaskan bahwa peran agenda-setting adalah kemampuan media massa untuk memengaruhi topik yang dianggap penting dalam agenda publik. Dalam bahasa Severin \& Tankard (1998: 264), agenda-setting merupakan gagasan bahwa media, melalui berita yang disampaikan, akan menentukan isu apa yang dianggap penting oleh publik. Konsep yang berhubungan erat dengan agenda-setting adalah agenda publik dan agenda kebijakan. Agenda media (urutan topik berdasar yang dianggap penting dalam media) memengaruhi baik agenda publik (urutan topik yang dianggap penting dalam survei terhadap opini khalayak) maupun agenda kebijakan (urutan topik yang dianggap penting dalam pikiran lembaga yang menentukan kebijakan publik).

Pada tahap selanjutnya media memiliki strategi yang disebut framing. Framing ini berasumsi bahwa media bisa membentuk perspektif tertentu, atau "memutar" (spin), terhadap peristiwa yang disajikannya. Dengan framing, agenda-setting tidak lagi hanya menanyakan 'what to think about', namun juga 'how to think about'. Media, untuk isu yang sama, memberikan framing yang berbeda terhadap atribut isunya. Akibatnya adalah kognisi khalayak akan dipengaruhi oleh pilihan framing media.

Penelitian ini menjadi gambaran demonstrasi agenda-setting dan framing oleh media. Media mengagendakan kepemimpinan nasional, maka pada level pertama akan muncul anggapan bahwa publik pun akan menempatkan isu ini menjadi penting juga. Penelitian ini menemukan bahwa Koran Sindo melakukan framing pada sosok calon presiden yang dinilai rival dari pemilik media tersebut.

Sosok Jokowi dimunculkan sebagai seorang Gubernur Jakarta. Pada saat itu memang Jokowi masih menjalankan amanatnya pada tahun kedua. Koran Sindo menampilkannya sebagai seorang Kepala Daerah dengan Berita yang berjudul "Pengelolaan APBD DKI Memburuk" berupaya menunjukkan kualitas kepemimpinan yang ditunjukkan Jokowi sebagai Gubernur. Pemunculan fakta negatif tentang kapasitas kepemimpinan Jokowi sebagai Gubernur DKI ini dinilai oleh peneliti sebagai sebuah upaya perlawanan isu. Selama ini, publik relatif mengenal sosok nomor satu di Jakarta ini sebagai seorang yang peduli dan bekerja untuk rakyat. Pemunculan fakta seperti ini diduga mampu membalik anggapan tersebut dalam perhelatan pemilihan presiden 2014. Dalam proses menuju pemilihan, pemilih diharapkan secara rasional melakukan pertimbangan terhadap kualitas kepemimpinan kandidat. Media punya peran untuk menampilkan hasil kinerja kepemimpinan seorang kandidat. Dugaan inilah yang diyakini peneliti mendorong Koran Sindo mengupayakan pemunculan fakta-fakta lain tentang Jokowi demi mencapai tujuan yang diinginkan.

Dampak framing yang demikian adalah ketika publik mencoba mencari dan mengidentifikasi kepemimpinan nasional pada tokoh tertentu sesuai dengan frame yang dikonstruksi media. Mengingat bahwa agendasetting berada pada domain dengan asumsi powerful media effect, maka sebenarnya efek media terhadap khalayak memang besar. Hanya saja tidak sertamerta demikian. Ada faktor-faktor yang mengekskalasi tingkat kekuatan pengaruh agenda-setting. Di antaranya adalah langsung atau tidak langsung jenis pengalaman terhadap isu yang sedang diagendakan, tingkat need for orientation yang ada pada khalayak, tingkat pendidikan, serta tingkat kredibilitas media yang melakukan setting terhadap agenda tertentu.

Media merupakan salah satu aktor penting dalam pegelaran pemilu 2014. 
Selain menjadi wadah informasi, media juga mempunyai peran menjadikan proses demokrasi di Indonesia akan semakin baik dan bermutu. Secara ideal, dalam setiap pemberitaannya selalu berusaha netral dan mengutamakan kepentingan bangsa dan negara. Dalam perkembangannya, idealisme tersebut semakin bergeser ke arah yang dikehendaki pemilik media itu sendiri. Fenomena tersebut tentunya mulai disuarakan ketika pemilihan legislatif sebelumnya, dan semakin gencar menjelang pemilu 2014. Tidak dapat dipungkiri jika beberapa konglomerat media saat ini menjadi bagian dari aktor dalam Pemilu 2014, sehingga netralitas media dalam pemilu 2014 sangat dipertanyakan.

Konflik kepentingan terjadi ketika media massa ditunggangi kepentingan pemiliknya. MenurutFortunato(2005),pemilik modal dapat menentukan dan memengaruhi konten media yang ditransmisikan ke publik karena penguasaannya terhadap dukungan anggaran dan organisasi media, proses seleksi dan framing, serta kekuasaan atas personalia yang mengelola media. Dengan kekuasaan yang dimiliki, media massa menjadi sarana untuk menggiring perhatian khalayak agar memperhatikan isu-isu tertentu, termasuk mengubah perhatian khalayak dari satu isu ke isu lainnya sesuai kepentingan politik pemiliknya. Transmisi informasi kemudian menjadi kebijakan pemilik media melalui seleksidanframing.Pemilikmediamenentukan informasi mana yang akan dikonsumsi oleh publik, kapan waktunya, berapa lama durasinya, seberapa sering intensitasnya, guna mendukung agenda-setting kekuatan politik yang diwakilinya. Bahkan, media massa dapat digunakan sebagai sarana black campaign untuk mendiskreditkan lawan-lawan politik dari pemilik media.

Keberadaan media massa yang netral ini penting bagi peningkatan kualitas demokratisasi politik. Netralitas media massa akan memberikan kesempatan yang fair dan setara bagi semua kontestan politik untuk memanfaatkan ruang publik dalam memengaruhi masyarakat. Begitu pula masyarakat akan memiliki akses informasi yang akurat, kredibel, dan beragam. Prinsip perlakuan yang fair dan setara inilah kondisi yang diperlukan dalam memperkuat demokrasi. Hal itu dapat terjadi jika para pemilik media dapat memisahkan antara kepentingan politiknya dan profesionalisme jurnalistik yang harus dijalankan oleh awak media.

\section{Simpulan}

Sebagai salah satu bentuk media komunikasi massa, surat kabar berperan membangun dan mengarahkan pandangan, opini, bahkan preferensi khalayak terhadap sebuah fenomena. Isu yang terdapat di media dibangun sedemikian rupa agar tidak kentara oleh khalayak bahwa isu tersebut merupakan bentukan, bukan seperti itu adanya. Kemudian perspektif khalayak bisa terpengaruh akan isu tersebut. Padahal isu yang dimunculkan media merupakan hasil pembingkaian dari banyak kepentingan yang saling bernegosiasi. Oleh sebab itu khalayak sebagai pembaca media perlu memaknai teks surat kabar yang ditampilkan tidak hanya dengan membaca apa yang tersurat, tetapi juga harus mampu melihat apa yang tersirat.

Para konstruktivis meyakini bahwa individu berperilaku dan berintrepretasi berdasarkan kategori konseptual yang terdapat di pikirannya. Realitas sosial yang dibentuk individu merupakan realitas yang terlihat, bukan realitas dalam bentuk sesungguhnya. Maka pembaca media harus menyadari bahwa teks yang disampaikan media tidak selalu memiliki nilai kebenaran dan objektivitas murni. Tetapi kebenaran tersebut adalah kebenaran media yang telah dikonstruksi dan dipengaruhi berbagai kepentingan yang ada.

Pada bagian awal penelitian ini telah dikemukakan pertanyaan yang ingin dijawab; yaitu bagaimanakah analisis framing tentang pemberitaan Jokowi yang dibuat oleh Koran Sindo pada masa kampanye terbuka pilpres 2014. Untuk menjawab pertanyaan penelitian tersebut, peneliti menggunakan model analisis 
framing dari Gamson-Modigliani. Model analisis ini digunakan karena menitikberatkan pada aspek di mana frame media terdiri dari gugusan ide yang dikonstruksikan dalam suatu kemasan (package), dan komunikator telah memberikan penafsiran terhadap apa yang diterima. Model Gamson-Modigliani menggunakan kerangka pembingkai yang terdiri dari aspek teks berupa metafora, catchphrases, exemplaar, depiction, gambar visual, dan eufemisme. Peneliti memandang aspek tersebut sangat tepat untuk menganalisis sebuah karya jurnalistik.

Gamson-Modigliani memandang frame sebagai sebuah cara bercerita atau gugusan ide yang tersusun sedemikian rupa dan menghadirkan konstruksi makna dari peristiwa yang berkaitan dengan suatu wacana. Menurut Gamson, wacana media merupakan elemen penting untuk memahami dan mengerti pendapat umum yang berkembang atas sebuah isu dan peristiwa. Agenda publik tidak cukup jika hanya didasarkan pada data survei khalayak. Data tersebut perlu dihubungkan dan diperbandingkan dengan bagaimana media mengemas sebuah isu. Gamson meyakini bahwa bagaimana media menyajikan sebuah isu menentukan bagaimana khalayak memahami sebuah isu.

Koran Sindo memiliki agenda tersendiri yang bisa saja berbeda dengan agenda publik. Oleh karena itu, dalam membaca teks media, khalayak harus mampu dengan cerdas membaca dan mengungkap makna yang tersembunyi dari sebuah peristiwa. Hasil penelitian ini menemukan bahwa dalam memberitakan calon presiden, masing-masing media itu memiliki konstruksi yang berbeda dan perbedaan ide gagasan yang cukup signifikan. Model analisis GamsonModigliani mampu memperlihatkan adanya agenda tersembunyi di balik teks berita yang disampaikan media.

Penelitian ini membuktikan bahwa isi media bukanlah sebuah cermin dari realitas yang sebenarnya, tetapi isi media dibentuk oleh berbagai faktor yang menghasilkan berbagai versi yang berbeda dari realitas. Ada faktor kepemilikan yang memberikan pengaruh pada agenda penyusunan teks media. Di Indonesia, struktur kepemilikan media bergerak menuju oligopoli, yaitu media yang dimiliki segelintir orang. Pemusatan kepemilikan media dinilai akan membahayakan independensi ruang redaksi pers, terutama ketika event suksesi seperti pilpres kemarin. Apalagi, bersatunya penguasa partai politik dan penguasa media bakal menempatkan posisi pers Indonesia menjadi lebih rentan terhadap berbagai intervensi politik kekuasaan.

\section{Daftar Pustaka}

Armando, Ade. 2014. Representasi Kepentingan Pemilik Media Dalam Pemberitaan Tentang Pesaing Politik (Kasus Pemberitaan oleh Grup Media MNC tentang Pencalonan Jokowi Sebagai Calon Presiden). Jakarta: Ikatan Sarjana Komunikasi Indonesia.

Curran, James dan Michael Gurevitch. 2005. Mass Media and Society, 4th Ed. London: Hodder Arnold.

Eriyanto. 2002. Analisis Framing; Konstruksi, Ideologi, dan Politik Media. Yogyakarta: LKIS.

Festinger, L. A. (1957). A Theory of Cognitive Dissonance. New York: Row Peterson.

Fortunato, John. A. 2005. Making Media Content. New Jersey: Lawrence Eribaum Associates. Inc. Publishers.

Hidayat, Dedi N. 2001. Analisis Wacana: Pengantar Analisis Teks Media. Yogyakarta: LKIS.

McCombs, Maxwell \& Reynolds, Amy. 2002. News Influence on Our Pictures of the World dalam Bryant, Jennings \& Zillman, Dolf. Media Effects: Advances in Theory and Research. New Jersey, London: Lawrance Erlbaum Associates.

McNair, Brian, 1997. An Introduction to Political Communication. New York: Routledge.

McQuail, Denis. 2002. McQuail's Reader in 
Mass Communication Theory. London: Sage Publications.

Nimmo, Dan. 1993. Komunikasi Politik; Khalayak dan Efek. Bandung: Rosdakarya.

Norris, Pippo, John Curtice, David Sanders, Margaret Scammel, and Holli A Semetko. 1999. On Message: Communicating The Campaign. London: SAGE Publications.

Nugroho, Bimo, Eriyanto, dan Frans Sudiarsis. 1991. Politik Media Mengemas Berita. Jakarta: ISAI.

Nugroho, Yanuar, Dinita Andriani Putri dan Shita Laksmi. 2012. Memetakan Lansekap Industri Media Kontemporer di Indonesia. Jakarta: CIPG dan HIVOS.

Severin, W. J, \& Tankard Jr., J. W .1998. Communication Theories: Origins, Methods, Uses. New York: Longman.

Shoemaker, P. J., \& Reese, S. D. 1996. Mediating The Message (2nd ed.). New
York: Longman Publisher.

Siahaan, Hotman M dkk. 2001. Pers yang Gamang: Studi Pemberitaan Jajak Pendapat Timor Timur. Surabaya: Lembaga Studi Perubahan Sosial.

Sobur, Alex. 2002. Analisis Teks Media: Suatu Pengantar untuk Analisis Wacana, Analisis Semiotik, dan Analisis Framing. Bandung: PT. Remaja Rosdakarya.

Subiakto, Henry \& Rachmah Ida. 2012. Komunikasi Politik, Media, \& Demokrasi. Jakarta: Kencana Prenada Media Group.

Wicks, R. H. 2005. Message Framing and Constructiong Meaning: An Emerging Paradigm in Mass Communication Research. dalam P. J. Kalbfleisch, Communication Yearbook 29 (pp. 333-360). New Jersey: Lawrence Erlbaum Associates Inc. 